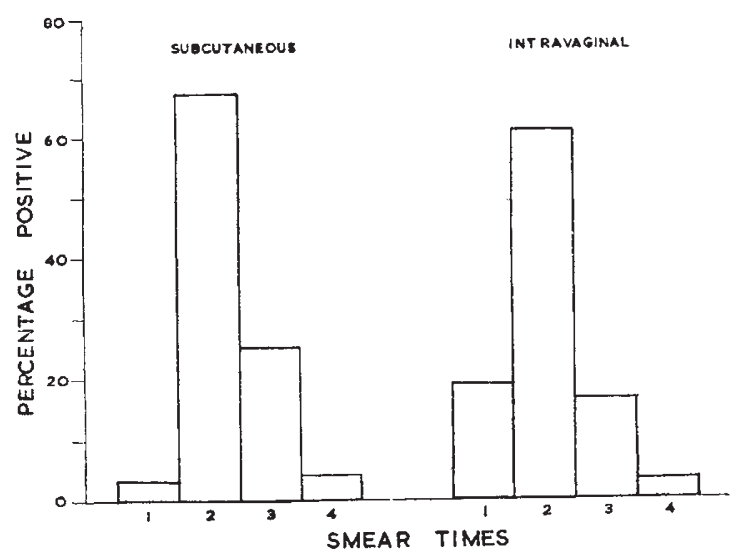

(2) Duration of cornification. Emmens ${ }^{4}$ showed that the duration of cornification with the subcutaneous route of administration depends on the dose of ostrogen administered. The effect of dose on the duration of cornification in the intravaginal method has been investigated. Smears were taken from the intravaginal groups in the second batch of animals throughout the period of cornification. Table 2 shows the times when negative smears returned.

Table 2. TIME OF Reappearance of Negative SMears IN THE ANIMAT\& REOEIVING TWO MAXIMAT, DOSE-LEVELS OF CESTRONE INTRAVAGINALLY

\begin{tabular}{|c|c|c|}
\hline Smear time & Low dose & High dose \\
\hline 4 & 18 & 9 \\
5 & 11 & 11 \\
6 & 11 & 15 \\
\hline
\end{tabular}

Although there might be a slight tendency for the effect of the high dose to persist for a longer period than the effect of the low dose, on statistical analysis no significant difference between the two distributions was detected $\left(\chi\left[{ }^{2}\right]=3.30, P>0.05\right)$. On the evidence available, therefore, there is no reason for supposing that dose-level influences the duration of cornification by the intravaginal method. However, it is possible that with wider dose intervals, such as those used by Emmens, differences in the duration of cornification would become apparent; this question requires further examination.

\section{J. D. BIGGERS}

Department of Veterinary Physiology, University of Sydney. April 28.

${ }^{1}$ Emmens, C. W., "Hormone Assay", Chapter 16 (Academic Press, New York, 1950).

${ }^{2}$ Freud, J., Acta brev. neerl. Physiol., 9, 11 (1939).

Biggers, J. D. (in the press).

¿ Emmens, C. W., J. Endocrinol., 1, 142 (1939).

\section{Two Forms of $1: 2: 3: 5$ Tetra-Acetyl D-Ribofuranose}

IN a recent communication, Davoll, Brown and Visser ${ }^{1}$ have described two forms of $1: 2: 3: 5$ tetraacetyl D-ribofuranose. The form first obtained had melting point $56^{\circ}-58^{\circ}$ and was probably identical with the compounds of Howard, Lythgoe and Todd ${ }^{2}$, and of Bredereck and Hoepfner ${ }^{3}$. This substance changed spontaneously into another, melting point $85^{\circ}$, proved to be identical with the $1: 2: 3: 5$ tetra-acetyl $\mathrm{D}$-ribofuranose of Zinner ${ }^{4}$. The transformation was reported to be accompanied by a change in specific rotation from $[\alpha]_{D}^{20}-3 \cdot 6^{\circ}$ to $-13 \cdot 5^{\circ}$ (in methanol).

Some time ago, I prepared this compound (using the method of Zinner ${ }^{4}$ ) in the lower-melting form (melting point $\left.56 \cdot 5^{\circ}-57^{\circ}\right)$. When a comparison with the highermelting form (generously provided by Dr. Zinner, of Jena) was attempted, the whole of the material isomerized, and the form of melting point $56.5^{\circ}-57^{\circ}$ can no longer be prepared in this laboratory. This isomerization, however, proceeded without any significant change in specific rotation; $[\alpha]_{D}^{22}$ for the low-melting form $-13 \cdot 2+1^{\circ}$; for the high-melting form $-12 \cdot 0 \pm 1^{\circ}$ (both in chloroform). The case thus seems to be a simple (though very striking) one of dimorphism, and the speculations of Davoll et al. ${ }^{1}$ regarding structural isomerism are probably unnecessary.

It would be of great interest, however, if workers in some laboratory uncontaminated with the highermelting form would re-examine the transformation polarimetrically, since there is a definite contradiction between the results of Davoll et al. ${ }^{1}$ and those $I$ have obtained.

\section{Kathrieen R. Farrar}

Chemistry Department,

University of Manchester. July 29.

'Davoll, J., Brown, G. B., and Visser, D. W., Nature, 170, 65 (1952).

${ }^{2}$ Howard, G. A., Lythgoe, B., and Todd, A. R., J. Chem. Soc., 1052 (1947).

${ }^{3}$ Bredereck, H., and Hoepfner, E., Ber., 81, 51 (1948).

- Zinner, H., Ber., 83, 153 (1950).

\section{Disadvantages of Race Mixture}

IN the modified Unesco statement on the nature of race, issued at the Fourth International Anthropological Congress in Vienna on September 7, we find the incautious affirmation that "there is no evidence that race mixture produces disadvantageous results from a biological point of view". To cite a single case, there is recent evidence ${ }^{1}$ that sickle-cell anæmia, a fatal disease, occurs with much higher frequency in American Negroes having some white ancestry than in African Negroes of pure descent, although the latter show a much higher frequency of the sicklæmia trait, which is without symptoms.

Similarly, the $R h$-negative gene, which is responsible for the death of countless Caucasian infants and fotuses, has been traced to prehistoric crossing between the Basques and peoples speaking the IndoEuropean languages. These crosses probably began at least as early as the Neolithic; but their effects on the death-rate of European infants and foetuses (erythroblastosis) are still unabated. Here is ample evidence that race mixture can be disadvantageous in its racial effects.

\section{R. RugGLes Gates}

The Athenæum,

London, S.W.1. Sept. 9.

${ }^{1}$ Lehmann, H., Nature, 167, 931 (1951). 